\title{
Efek Ekstrak Propolis terhadap Ekspresi TNF- $\alpha$, Apoptosis dan Nekrosis Jaringan Otak Tikus Model Traumatic Brain Injury (TBI)
}

\section{The Effects of Propolis Extract on Brain TNF- $\alpha$ Expression, Apoptosis and Necrosis in Rat Model of Traumatic Brain Injury}

\author{
Ashalia Chandra $D^{1}$, Mulyohadi Ali ${ }^{2}$, Hari Purnomo \\ ${ }^{1}$ Laboratorium Ilmu Penyakit Saraf Rumah Sakit Umum Daerah Dr. Saiful Anwar Malang \\ ${ }^{2}$ Laboratorium Farmakologi Fakultas Kedokteran Universitas Brawijaya Malang
}

\begin{abstract}
ABSTRAK
Ekstrak propolis merupakan produk lebah dengan berbagai kandungan aktif yang memiliki efek antioksidan, antiinflamasi, proteksi DNA, neuroprotektan dan immunomodulator. Propolis mampu menurunkan reaksi inflamasi melalui hambatan terhadap aktivitas TNF- $\alpha$ dan NF- $\kappa$ B, mampu menurunkan Bax dan caspase-3, dan meningkatkan Bcl-2, yang berperan pada jalur apoptosis. Propolis berpotensi sebagai terapi alternatif dalam menurunkan inflamasi, apoptosis dan nekrosis pada traumatic brain injury (TBI) via modulasi ekspresi TNF- $\alpha$. Penelitian ini bertujuan untuk menguji pengaruh pemberian ekstrak propolis dalam berbagai dosis pada ekspresi TNF- $\alpha$, apoptosis dan nekrosis pada jaringan otak tikus model TBI. Sampel dibagi menjadi 5 kelompok, yaitu: kontrol negatif, kontrol positif, kelompok model trauma dan diberi perlakuan propolis masing-masing dosis 50,100 , dan $200 \mathrm{mg} / \mathrm{kgBB} / \mathrm{h}$. Pada akhir penelitian, tikus dikorbankan dan dibuat preparat otak untuk menilai ekspresi TNF- $\alpha$, jumlah sel apoptosis dan area nekrosis. Ekspresi TNF- $\alpha$, apoptosis dan nekrosis lebih rendah pada kelompok TBI yang mendapatkan ekstrak propolis 50, 100, dan 200mg/kgBB/h ( $p=0,000)$. Penelitian ini membuktikan bahwa ekstrak propolis berpengaruh dalam penurunan ekspresi TNF- $\alpha$, apoptosis dan nekrosis jaringan otak tikus model TBI.
\end{abstract}

Kata Kunci: Apoptosis, ekstrak propolis, ekspresi TNF- $\alpha$, nekrosis, traumatic brain injury

\begin{abstract}
Propolis extract is honey bee product that has many active ingredients with many important roles, i.e. as antioxidant, antiinflamation, DNA protection, neuroprotectant and immunomodulator. Propolis can reduce the inflammatory reaction by inhibiting the activity of TNF- $\alpha$ and NF-KB. Propolis can also decrease Bax and caspase 3, and increase Bcl-2, which have role in apoptosis pathway. Thus, propolis is a potential alternative therapy for traumatic brain injury by reducing inflammation, apoptosis, and necrosis via TNF- $\alpha$ expression modulation. This study aims to evaluate the effect of propolis at various doses on brain TNF- $\alpha$ expressions, apoptosis and necrosis in rat model of traumatic brain injury. The rats were divided into 5 groups, namely negative control, positive control, and traumatic brain injury groups treated with propolis at doses of 50,100, and $200 \mathrm{mg} / \mathrm{kgBB} / \mathrm{d}$, respectively. At the end of study, the rats were sacrificed and their brains were isolated and processed histologically to assess TNF- $\alpha$ expression, apoptosis, and necrosis. Results showed that TNF- $\alpha$ expression, apoptosis, and necrosis were lower in TBI groups treated with ethanol extract of propolis 100 and $200 \mathrm{mg} / \mathrm{kgBB} / \mathrm{d}(\mathrm{p}=0,000)$. This study shows that propolis can decrease brain TNF- $\alpha$ expression, apoptosis, and necrosis in the rat model of traumatic brain injury.
\end{abstract}

Keywords: Apoptosis, necrosis, propolis extract, TNF- $\alpha$ expression, traumatic brain injury

Korespondensi: Ashalia Chandra D. Laboratorium IImu Penyakit Saraf Rumah Sakit Umum Daerah Dr. Saiful Anwar Malang, Jl. JA. Suprapto No. 2 Tel. (0341) 366242 Email: ashaliachandra@yahoo.co.id 


\section{PENDAHULUAN}

Cedera otak atau Traumatic brain injury (TBI) merupakan penyebab utama morbiditas dan mortalitas pada semua kelompok umur, terutama dewasa muda. Di Indonesia data epidemiologi hingga saat ini belum tersedia, namun dari data yang ada dikatakan dari tahun ke tahun mengalami peningkatan (1-3).

TBI merupakan suatu kerusakan pada kepala yang disebabkan oleh serangan atau benturan fisik dari luar, yang dapat menyebabkan kematian sel sampai terjadi disfungsi neurologi terhadap jaringan $(4,5)$. Cedera kepala dapat terjadi secara langsung (cedera primer) maupun melalui kerusakan endogen dalam otak dan efek tambahan sekunder otak, yang merupakan kelanjutan dari cedera primer (cedera sekunder). Selama cedera kepala terjadi berbagai mekanisme yang mengikuti, salah satunya mekanisme respon inflamasi dengan munculnya sitokin baik proinflamasi maupun anti inflamasi (6-8). Salah satu sitokin proinflamasi utama yang muncul saat TBI adalah tumor necrosis factor- $\alpha$ (TNF- $\alpha$ ). Pada proses $\mathrm{TBI}, \mathrm{TNF}-\alpha$ memiliki beberapa fungsi biologis diantaranya berfungsi untuk aktivasi jalur survival, yang dalam aktivitasnya menggunakan jalur Nuclear factor kappa $B$ (NF-B), maupun jalur apoptosis yang dalam aktivitasnya menggunakan caspase (9-11). Mekanisme apoptosis terjadi melalui dua jalur, yaitu caspase-dependent dan caspase-independent. Caspase-dependent pathway dapat melalui jalur intrinsik yang dipicu oleh kegagalan metabolik mitokondria atau jalur ekstrinsik yaitu kelompok reseptor TNF- $\alpha$. Sedangkan jalur caspaseindependent tidak membutuhkan perantara caspase. Jalur ini mempunyai mekanisme tersendiri menuju kematian sel. Sepertiga kematian sel berhubungan dengan caspase-dependent apoptosis, sepertiga yang lain caspase-independent, dan sepertiga sisanya berhubungan dengan nekrosis (12-14).

Sampai saat ini, terapi untuk mencegah cedera sekunder atau mengurangi tingkat keparahan yang diakibatkan oleh cedera sekunder banyak memiliki kekurangan saat diaplikasikan secara klinis (15). Pada umumnya terapi TBI merupakan terapi suportif neurointensif yang difokuskan pada pengendalian hipertensi intrakranial (16). Efek terapi anti-inflamasi seperti dijelaskan melalui penelitian bahwa TNF- $\alpha$ in vitro dan in vivo dapat melindungi neuron dari reaksi eksitotosik, stres oksidatif dan cedera iskemik. Selain itu, terapi yang berorientasi sebagai anti inflamasi telah menunjukkan bukti pengaruh neuroprotektif pada model hewan (17).

Propolis adalah produk lebah, yang memiliki kandungan aktif flavonoid tinggi yang dapat berperan sebagai antioksidan (18). Beberapa penelitian menunjukkan bahwa propolis memiliki aktivitas antioksidan dan antiinflamasi yang kuat. Flavonoid mempunyai efek neuroprotektan yang dapat menurunkan Bax, meningkatkan $\mathrm{Bcl}-2$ dan menurunkan caspase-3 (19-21). Selain itu, propolis mampu menurunkan reaksi inflamasi yang terjadi melalui hambatan terhadap aktivitas TNF- $\alpha$ dan NF-KB, sehingga diharapkan dapat mencegah komplikasi cedera sekunder yang mungkin terjadi $(22,23)$. Propolis juga menunjukkan pemulihan aktivitas sintesis glutamat dan nitric oxide (NO) dengan penurunan stres oksidatif yang diperantarai eksitotoksisitas, sehingga propolis juga dapat menghambat terjadinya nekrosis melalui jalur tersebut (24).

Hal ini menunjukkan bahwa propolis memiliki potensi sebagai alternatif terapi dalam menurunkan ekspresi TNF$\alpha$, apoptosis dan nekrosis pada TBI. Dengan demikian, pemberian propolis diharapkan dapat mencegah komplikasi cedera sekunder yang mungkin terjadi. Berdasarkan latar belakang diatas, dilakukan penelitian mengenai pengaruh pemberian propolis pada tikus model cedera otak traumatik.

\section{METODE}

\section{Desain Penelitian}

Penelitian ini menggunakan desain eksperimen murni (true experimental design) secara in vivo dengan Randomized Post Test Only Controlled Group Design pada hewan model Rattus norvegicus galur wistar. Kriteria inklusi yang digunakan adalah tikus putih wistar, jantan, usia 6-8 minggu, berat antara 150-200 gram, sehat dan aktif, dan kriteria drop out tikus yang sakit dan mati pada saat penelitian berlangsung.

Dalam penelitian ini, terdapat tiga kelompok perlakuan dan dua kelompok kontrol, yaitu: kelompok A (kontrol negatif, tanpa trauma otak dan tanpa diberi ekstrak propolis.), kelompok B (kontrol positif, model cedera otak traumatik tanpa diberi ekstrak propolis.), kelompok C (model cedera otak traumatik dan diberikan propolis $50 \mathrm{mg} / \mathrm{kgBB}$ ), kelompok $\mathrm{D}$ (model cedera otak traumatik dan diberikan propolis $100 \mathrm{mg} / \mathrm{kgBB}$ ), dan kelompok $\mathrm{E}$ (model cedera otak traumatik dan diberikan ekstrak propolis $200 \mathrm{mg} / \mathrm{kgBB}$ ). Setiap kelompok terdiri dari 4 ekor tikus.

Semua protokol yang berkaitan dengan hewan coba telah mendapat persetujuan Komite Etik Penelitian Kesehatan Fakultas Kedokteran Universitas Brawijaya (387C/EC/KEPK-PPDS/07/2015).

Pemeliharaan hewan coba sebanyak 20 tikus dibeli dan dipelihara di Laboratorium Farmakologi Fakultas Kedokteran Universitas Brawijaya. Tikus dipelihara dalam kandang $20 \times 30 \mathrm{~cm}$ dan diaklimatisasi (diadaptasi) selama 7 hari. Dasar kandang dilapisi dengan sekam padi setebal 1,5-2cm dan diganti dalam interval seminggu sebanyak dua kali penggantian. Sekam yang diberikan terlebih dahulu dibersihkan dan disaring dari debu maupun kotoran lainnya. Kandang dan tempat minum dicuci setiap tiga hari sekali. Makan dan minum diberikan sehari sekali dengan jumlah yang cukup untuk setiap kandangnya. Untuk makanan tikus setiap harinya sebanyak 15-40gram pellet. Untuk minum diberikan air matang yang diganti setiap hari dan diberikan ad libitum. Untuk menghindarkan terjangkitnya penyakit posisi kandang dijauhkan dari hewan coba lain yang diberi paparan penyakit tertentu serta dihindarkan dari predator.

\section{Model Cedera Otak Traumatik}

Tikus dianestesi kemudian bulu kepala dicukur dan dibersihkan dengan alkohol 70\%. Kemudian kulit kepala dibuka. Silinder besi seberat 45 gram (diameter $4 \mathrm{~mm}$ ) dijatuhkan dengan sudut 90 dari ketinggian $100 \mathrm{~cm}$ sebanyak 1 kali. Benturan dengan energi 0,5 joule (26).

\section{Ekstraksi Propolis}

Teknik ekstraksi diawali dengan pembuatan rendemen propolis dari propolis kasar. Langkah pertama adalah 
mengekstraksi propolis dengan etanol sebagai pelarut dengan perbandingan propolis: etanol adalah 1:10. Alat yang digunakan yaitu Thermostirer berkecepatan 150rpm selama 4 jam dan diputar dengan bantuan Magnetic Stirrer $5 \mathrm{~cm}$. Hasilnya disaring dengan menggunakan kertas saring sehingga didapat filtrat propolis. Filtrat dipisahkan dari pelarut dengan cara penguapan dalam rotary evaporator pada suhu $\pm 70^{\circ} \mathrm{C}$ berkecepatan 2-3rpm. Rendemen yang diperoleh tersebut kemudian diencerkan dengan E-pure dan Tween 80. Rendemen diencerkan dengan tujuan agar rendemen propolis yang bersifat lengket tersebut dapat lebih mudah diberikan pada hewan coba melalui metode oral. Terapi propolis diberikan secara peroral menggunakan sonde setiap hari selama 7 hari dengan dosis 50, 100, dan 200mg/kgBB/h.

\section{Pengambilan Jaringan Otak}

Pembedahan tikus dilakukan dengan memberikan anestesi terlebih dahulu. Anestesi diberikan dengan injeksi ketamine $1 \mathrm{mg} / \mathrm{kg}$ bb secara intramuskular. Setelah tikus dipastikan tidak sadar (tidak menunjukkan gerakan spontan), tikus dikorbankan dan dilakukan pembedahan untuk mengambil jaringan otak tikus. Hemisfer otak sisi kiri diambil dan dimasukkan kedalam botol yang telah diisi larutan formalin $10 \%$. Selanjutnya dilakukan pengirisan jaringan otak dan pembuatan slide dengan paraffin block.

\section{Pemeriksaan TNF- $\alpha$ dengan Teknik Imunohistokimia}

Deparafinasi slide dilakukan dengan pemanasan $60^{\circ} \mathrm{C}$ selama 60 menit, kemudian perendaman berturut-turut dalam larutan xylol ( $2 \times 10$ menit), etanol absolut $(2 \times 10$ menit), etanol $90 \%$ ( $1 \times 5$ menit), etanol $80 \%$ ( $1 \times 5$ menit), etanol 70\% ( $1 \times 5$ menit), dan akuades steril ( $3 \times 5$ menit). Antigen Retrieval dilakukan dengan merendam slide dalam bejana berisi dapar sitrat $\mathrm{pH}$ 6,0, kemudian dipanaskan dalam penangas air $95^{\circ}$ selama 20 menit. Selanjutnya slide dikeluarkan dari penangas dan ditunggu sampai suhu ruang selama \pm 20 menit. Slide dicuci dengan PBS pH 7,4 ( 3 x 5 menit). Dilakukan Blocking endogenous peroxidase menggunakan $3 \% \mathrm{H}_{2} \mathrm{O}_{2}$ selama 15 menit pada suhu ruang. Slide dicuci menggunakan PBS pH 7,4 tiga kali, selama 5 menit. Blocking unspecific protein menggunakan $3 \%$ FBS yang mengandung $0,25 \%$ Triton $\mathrm{X}-100$. Kemudian slide dicuci menggunakan PBS pH 7,4 tiga kali, selama 5 menit dan diinkubasi menggunakan rabbit polyclonal anti TNF- $\alpha$ (Santa Cruz), pada suhu $4^{\circ} \mathrm{C}$ selama semalam. Selanjutnya slide dicuci kembali menggunakan PBS pH 7,4 tiga kali, selama 5 menit dan diinkubasi menggunakan antibodi sekunder berlabel biotin conjugated selama 60 menit. Slide dicuci kembali menggunakan PBS pH 7,4 tiga kali, selama 5 menit dan diinkubasi dalam SA-HRP selama 40 menit, dicuci dengan PBS $3 \times 5$ menit, dan terakhir dicuci dengan akuades selama 10 menit. Selanjutnya ditetesi dengan Diamino Benzidine (DAB) dan diinkubasi selama 10 menit. Selanjutnya slide dicuci menggunakan aquades $3 \times 5$ menit, dilakukan counterstaining menggunakan Mayer's Hematoxylin yang diinkubasi selama 10 menit dan dicuci menggunakan $\mathrm{dH}_{2} \mathrm{O}$ dan dikeringanginkan. Langkah terakhir adalah proses Mounting menggunakan entelan dan ditutup dengan cover glass. Selanjutnya dilakukan pengamatan dibawah mikroskop binokuler (Olympus BxS1). Sel yang mengekspresikan TNF- $\alpha$ menunjukkan sitoplasma berwarna coklat. Pengukuran dilakukan dengan cara menghitung sel neuron dan glia yang mengekspresikan
TNF- $\alpha$ dibagi dengan seluruh jumlah sel perlapangan pandang, dilakukan sebanyak 10 lapang pandang, kemudian dirata-rata dalam bentuk prosentase dan dianalisa secara statistik. Pemeriksaan dilakukan oleh 2 orang peneliti sebanyak 2 kali pemeriksaan.

Pemeriksaan Apoptosis dengan Teknik DNA Terfragmentasi(Tunel)

Penyiapan slide dilakukan untuk pengecatan imunohistokimia dilakukan menggunakan metode standar seperti telah dijelaskan sebelumnya. Pengecatan untuk mendeteksi DNA terfragmentasi dilakukan menggunakan, kit Tunel fragmented DNA labeling (Roche, In Situ Cell Death Detection Kit, POD, Germany) sesuai petunjuk kit. Warna dimunculkan dengan metode standar Peroxidase DAB seperti telah dijelaskan sebelumnya dan dilakukan Counterstaining dengan Mayer's hematoxylin. Sel yang mengekspresikan apoptosis akan menunjukkan warna coklat pada inti sel. Pengukuran dilakukan dengan cara menghitung sel neuron dan glia yang mengalami apoptosis dibagi dengan seluruh jumlah sel perlapangan pandang, dilakukan sebanyak 10 lapang pandang, kemudian diratarata dalam bentuk prosentase dan dianalisis secara statistik.

\section{Pengamatan Area Nekrosis Jaringan Otak Dengan Pewarnaan Hematoxylin-Eosin}

Deparafinasi slide dilakukan sesuai standar seperti telah dijelaskan sebelumnya, sedangkan pewarnaan dilakukan menggunakan Hematoxylin-Eosin (10 menit), dilanjutkan dengan pencucian dengan air mengalir selama 30 menit dan dibilas akuades. Pewarnaan eosin alkohol dilakukan selama 5 menit. Dehidrasi dilakukan dengan pencucian pada etanol 80\%, 90\%, 95\% dan absolute, serta clearing pada xylol. Pengamatan dilakukan untuk mengidentifikasi area nekrosis yang ditunjukan berwarna lebih pucat dibandingkan area sekitarnya. Penilaian dilakukan secara kualitatif.

\section{Analisis Statistik}

Data pada pemeriksaan TNF- $\alpha$ dan apoptosis dianalisis secara statistik dengan menggunakan uji one-way ANOVA, dilanjutkan dengan Post Hoc Test (Tukey HSD), uji Korelasi Pearson, dan regresi linier. Hasil uji statistik dianggap bermakna secara statistik bila $p<0,05$.

\section{HASIL}

Pengaruh Pemberian Ekstrak Propolis terhadap Ekspresi TNF- $\alpha$ Pada Jaringan Otak Tikus Model TBI

Pemberian ekstrak propolis menurunkan ekspresi TNF- $\alpha$ pada tikus TBI (gambar 1 dan 2). Hasil analisis statistik ekspresi TNF- $\alpha$ pada jaringan otak tikus model TBI menunjukkan bahwa terdapat perbedaan yang nyata antar perlakuan (Anova $\mathrm{p}=0,000$ ). Hasil analisis uji Tukey, menunjukan bahwa pemberian ekstrak propolis berbagai dosis memberikan hasil rata-rata pada ekspresi TNF- $\alpha$ yang saling berbeda signifikan, tetapi pada dosis 2 dan 3 tidak didapatkan perbedaan yang signifikan. Analisis korelasi Pearson menunjukan bahwa terdapat hubungan terbalik antara dosis ekstrak propolis dengan TNF- $\alpha(p<0,05)$, sedangkan berdasarkan analisis regresi didapatkan $81,1 \%$ nilai TNF- $\alpha$ dipengaruhi oleh dosis ekstrak propolis $(R$ Square $\left(R^{2}\right)=0,811$ ) sedangkan sisanya sebesar $18 \%$ dipengaruhi oleh faktor lain diluar dosis ekstrak propolis yang diberikan. 

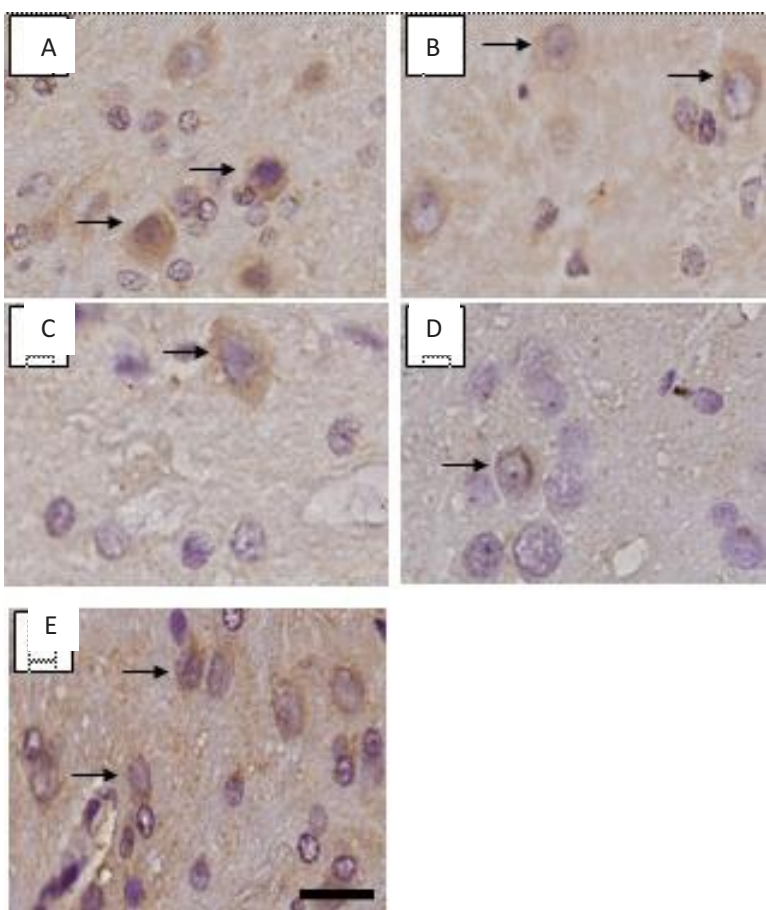

Gambar 1. Hasil pengecatan Imunohistokimia kelompok kontrol dan kelompok perlakuan menggunakan antibodi TNF- $\alpha$ Keterangan: Sel yang mengekspresikan TNF- $\alpha$ menunjukkan sitoplasma berwarna coklat. Tanda panah menunjukkan sel dengan ekspresi TNF- $\alpha$.

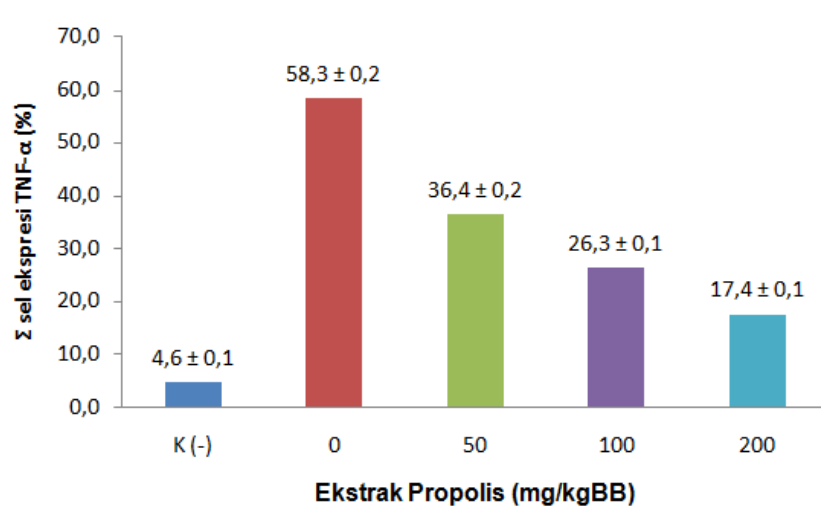

Gambar 2. Grafik histogram ekpresi TNF- $\alpha$ kelompok kontrol dan kelompok perlakuan

Pengaruh Pemberian Ekstrak Propolis terhadap Apoptosis pada Jaringan Otak Tikus Model TBI

Pemberian ekstrak propolis menurunkan apoptosis pada tikus TBI (gambar 3 dan 4). Hasil analisis statistik apoptosis pada jaringan otak tikus model TBI menunjukkan bahwa terdapat perbedaan yang nyata antar perlakuan (ANOVA $p=0,000$ ). Hasil analisis uji Tukey, menunjukan bahwa pemberian ekstrak propolis berbagai dosis memberikan hasil rata-rata pada apoptosis yang saling berbeda signifikan. Analisis korelasi Pearson menunjukan bahwa terdapat hubungan terbalik antara dosis ekstrak propolis dengan apoptosis $(p<0,05)$, sedangkan berdasarkan analisis regresi didapatkan $86 \%$ nilai apoptosis dipengaruhi oleh dosis ekstrak propolis ( $R$ Square $\left(R^{2}\right)=0,860$ ) sedangkan sisanya sebesar $14 \%$ dipengaruhi oleh faktor lain di luar ekstrak propolis yang diberikan.
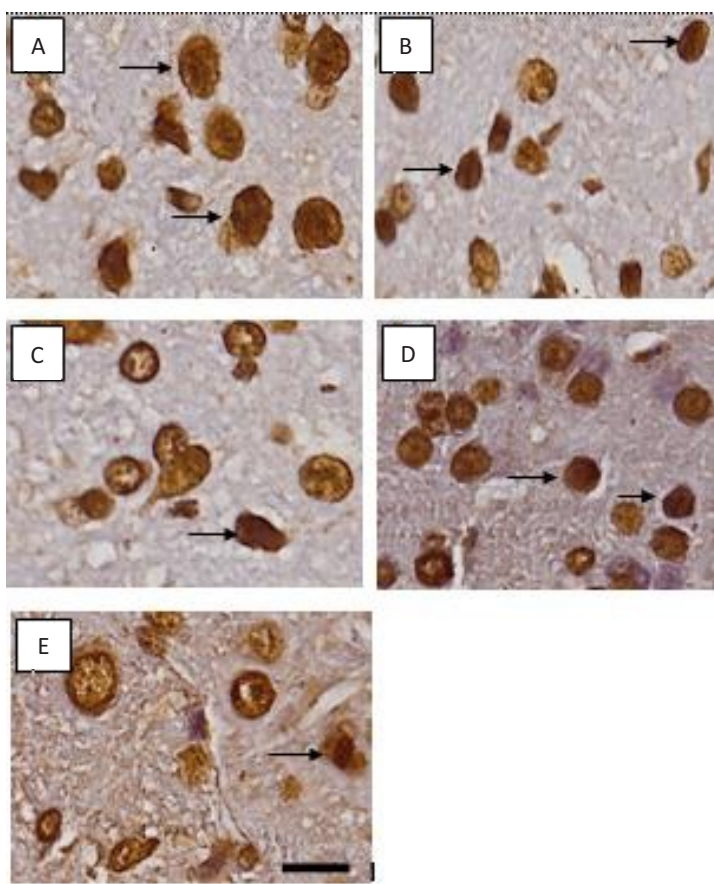

Gambar 3. Ekspresi apoptosis dengan imunohistokimia Tunel Assay (panah hitam) pada kelompok kontrol dan kelompok perlakuan

Keterangan: Sel apoptosis ditunjukan dengan warna coklat pada inti sel.

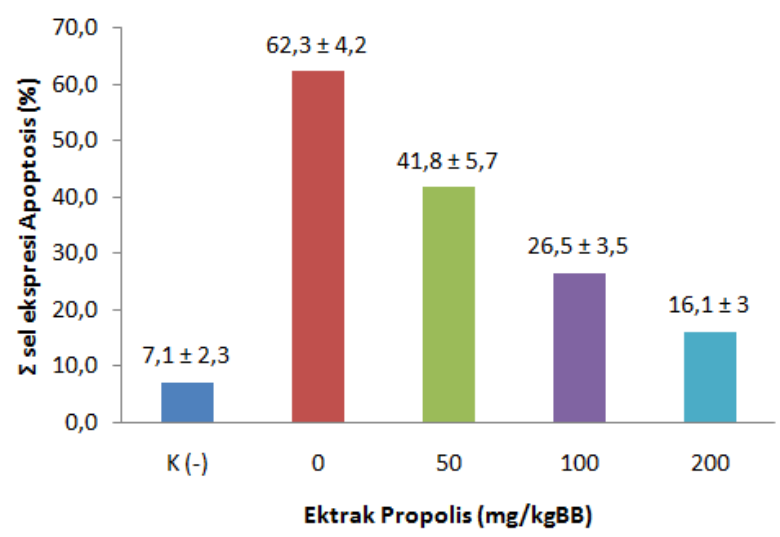

Gambar 4. Grafik histogram rata-rata nilai apoptosis kelompok kontrol dan kelompok perlakuan

Pengaruh Pemberian Ekstrak Propolis terhadap Penurunan Area Nekrosis pada Jaringan Otak Tikus Model TBI

Untuk mengetahui adanya pemberian ekstrak propolis dengan penurunan area nekrosis, dilakukan penilaian secara kualitatif. Hasil penilaian ditunjukan padaTabel 1.

Tabel 1. Hasil penilaian kualitatif pada area nekrosis dengan dosis perlakuan

\begin{tabular}{lc}
\hline \multicolumn{1}{c}{ Dosis Perlakuan } & Area Nekrosis \\
\hline Kontrol - & - \\
Kontrol + & + \\
$50 \mathrm{mg} / \mathrm{kgBB} / \mathrm{h}$ & + \\
$100 \mathrm{mg} / \mathrm{kgBB} / \mathrm{h}$ & - \\
$200 \mathrm{mg} / \mathrm{kgBB} / \mathrm{h}$ & - \\
\hline
\end{tabular}


Perlakuan kontrol (-), dosis 100 dan $200 \mathrm{mg} / \mathrm{kgBB} / \mathrm{h}$ tidak menunjukan adanya nekrosis sedangkan perlakuan kontrol (+) dan dosis $50 \mathrm{mg} / \mathrm{kgBB} / \mathrm{h}$ menunjukkan adanya nekrosis (gambar 5), sehingga dapat disimpulkan bahwa ekstrak propolis memberikan pengaruh terhadap area nekrosis pada jaringan otak TBI.
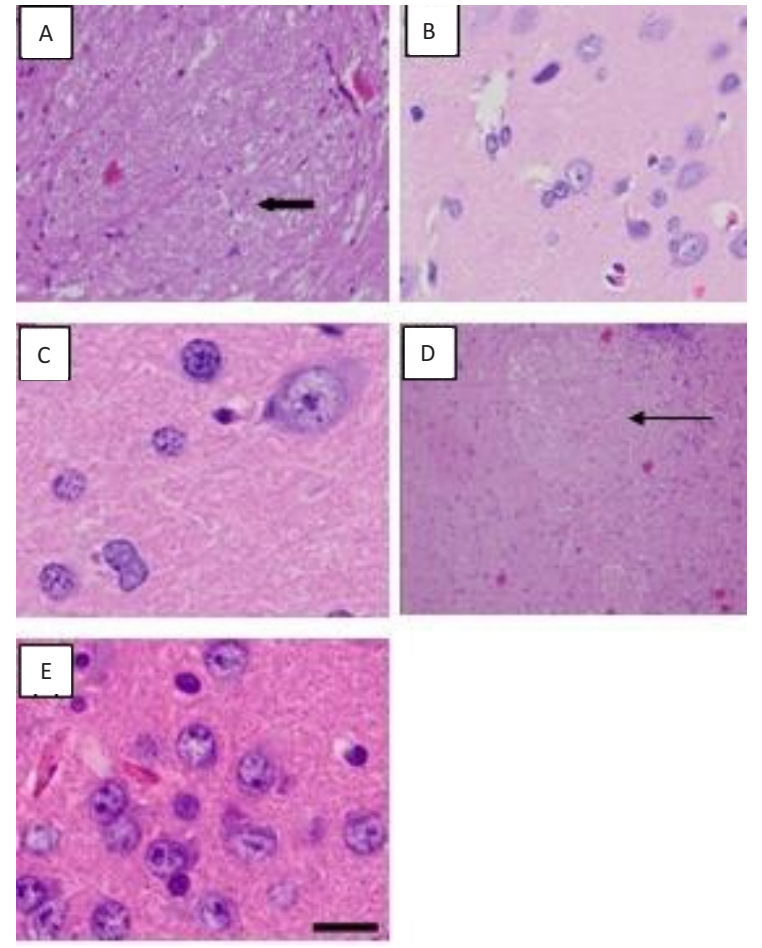

Gambar 5. Area nekrosis yang didapatkan pada pewarnaan Hematoxylen-Eosin (panah hitam) pada kelompok kontrol dan perlakuan

Keterangan: Area nekrosis ditunjukan berwarna lebih pucat dibandingkan area sekitarnya (tanda panah).

\section{DISKUSI}

Pengaruh Pemberian Ekstrak Propolis terhadap Ekspresi TNF- $\alpha$

Penurunan ekspresi TNF- $\alpha$ setelah perlakuan dosis propolis pada penelitian ini dapat dijelaskan seperti berikut. Propolis adalah produk lebah, yang mengandung flavonoid tinggi yang mempunyai efek antioksidan dan anti inflamasi yang kuat. Propolis mampu menurunkan reaksi inflamasi melalui hambatan terhadap aktifitas TNF dan NF-kB (27). Penelitian lain menunjukan bahwa ekstrak propolis mempunyai efek anti inflamasi lokal dan sistemik yang dihasilkan dari aksi immunomodulator. Ekstrak ini juga mampu memodulasi produksi sitokin proinflamasi dan antiinflamasi, mencegah penguatan proses inflamasi di paru (28).

Propolis juga mempunyai komponen neuroprotektif yaitu Caffeic acid phenethyl ester (CAPE) yang dapat menekan reperfusi iskemia akibat cedera otak dan melindungi medula spinalis dari cedera iskemia reperfusi (29). Penelitian lain menyebutkan bahwa propolis dapat menurunkan prostaglandin, leukotrin, sitokin proinflamasi (TNF- $\alpha$, interleukin-6(IL-6), interleukin-8(IL8)), dan meningkatkan interleukin-10 (IL-10) (30). Selain itu, studi menunjukkan bahwa propolis menurunkan aktivitas Nitric oxyde synthase (NOS), caspase-3, nitric oxide (NO), konsentrasi TNF- $\alpha$ dan kinase $A$ (KA) yang diperantarai oleh jalur eksitotoksisitas. Oleh karena itu propolis dapat menjadi agen pelindung terhadap gangguan eksitotoksisitas (31).

Dengan demikian, penurunan ekspresi TNF- $\alpha$ pada penelitian ini kemungkinan disebabkan oleh karena adanya komponen yang terkandung dalam ekstrak propolis yaitu flavonoid dan CAPE yang dapat menghambat ekspresi TNF- $\alpha$.

\section{Pengaruh Pemberian Ekstrak Propolis terhadap Apoptosis}

Penurunan jumlah sel apoptosis setelah pemberian perlakuan propolis dapat dijelaskan seperti berikut ini. Apoptosis adalah kematian sel yang digambarkan sebagai perubahan pada sel (menyusut) dan kondensasi nuklear, fragmentasi DNA dan formasi apoptosis bodies. Apoptosis membutuhkan kaskade intraseluler untuk menyelesaikan kematian sel, selanjutnya disebut sebagai kematian sel yang terprogram Mekanisme apoptosis terjadi melalui dua jalur, yaitu caspase-dependent dan caspase-independent. Caspase-dependent pathway dapat melalui jalur intrinsik yang dipicu oleh kegagalan metabolik mitokondria atau jalur ekstrinsik yang dipicu oleh "reseptor kematian", yaitu kelompok TNF reseptor. Caspase-independent pathway dipicu oleh protein mitokondria seperti Apoptosis Inducing Factor (AIF) yang keluar dari membran mitokondria akibat depolarisasi membran luar mitokondria $(32,33)$.

Propolis diketahui mempunyai kandungan flavonoid yang tinggi. Flavonoid mempunyai efek neuroprotektan seperti yang dilaporkan pada penelitian tikus model focal cerebral ischemia, yang hasilnya signifikan menurunkan Bax, meningkatkan $\mathrm{Bcl}-2$, dan menurunkan caspase-3. Penelitian pada tikus dengan perlakuan trauma medula spinalis yang diberikan ekstrak propolis dengan dosis $100 \mathrm{mg} / \mathrm{kgbb}$ dan $200 \mathrm{mg} / \mathrm{kgbb}$ pada 30 menit dan 4 jam setelah trauma menunjukkan bahwa ekstrak propolis dapat menurunkan apoptosis sel otak tikus melalui penurunan caspase-3 sebagai penanda apoptosis sel (34).

Beberapa penelitian juga telah melaporkan bahwa ekstrak propolis dimana terkandung CAPE menunjukkan potensi yang besar dalam modulasi kaskade asam arakhidonat. Penelitian lain melaporkan bahwa CAPE menunjukkan pengaruh inhibisi pada produksi sitokin proinflamasi IL-1 $\beta$, TNF- $\alpha$, dan MCP-1 (35). Propolis mempunyai komponen neuroprotektif melalui pengaruh antioksidan, anti inflamasi dan immunomodulator. Oxygen-derived free radical mempunyai implikasi terhadap patogenesis cedera otak setelah iskemia-reperfusi. CAPE memiliki kemampuan sebagai antioksidan. Pemberian CAPE dan alfa-tokoferol menekan reperfusi iskemia akibat peroksidasi lipid pada serebri. Terapi CAPE secara signifikan menghambat produksi reactive oxygen species (ROS) yang diinduksi oleh penyakit autoimmune encephalomyelitis (EAE) dan menunjukan perbaikan gejala klinis pada tikus. Hasil ini menunjukkan bahwa CAPE mempunyai efek antiinflamasi melalui inhibisi pada produksi ROS pada level transkripsi melalui supresi aktivasi NF-KB, dan dengan hambatan langsung pada aktivitas katalitik dari inducible Nitic Oxide Synyhase (iNOS) (36). Dengan demikian, penurunan jumlah sel apoptosis pada penelitian model tikus TBI ini kemungkinan disebabkan oleh karena adanya kandungan flavonoid dan CAPE dari ekstrak propolis. 
Pengaruh Pemberian Ekstrak Propolis terhadap Penurunan Area Nekrosis

Penurunan atau tidak adanya area nekrosis setelah perlakuan pemberian ekstrak propolis dapat dijelaskan sebagai berikut. Kematian sel pada otak terbagi menjadi dua yaitu apoptosis dan nekrosis, dimana banyak mekanisme yang mendasari terjadinya kematian sel akibat cedera kepala. Iskemia dan hipoksia yang menyertai cedera otak memicu terjadinya berbagai mekanisme yang menyebabkan influx $\mathrm{Ca}^{2+}$ ke dalam sel sehingga terjadi penumpukan ion $\mathrm{Ca}^{2+}$. Penumpukan ion $\mathrm{Ca}^{2+}$ yang berlebihan di dalam sel akan mengaktifkan enzim-enzim seperti protease, lipase, dan endonuklease yang akan mengakibatkan perubahan pada fosfolipid yang merupakan bagian dari membrane sel. Selanjutnya akan terjadi mobilisasi asam arakhidonat yang diproses oleh lipooksigenase dan siklooksigenase dalam sitosol menjadi leukotriens, prostaglandin, dan tromboksan. Proses ini akan disertai dengan pelepasan radikal bebas oksigen yang mengakibatkan peroksidasi membran sel. Penumpukan ion $\mathrm{Ca}^{2+}$ di dalam sel juga akan mengaktifkan enzim NOS sehingga terbentuk NO. NO akan bereaksi dengan radikal bebas oksigen sehingga terbentuk peroksinitrit, suatu senyawa yang sangat reaktif yang akan memacu peroksidasi lipid. Peroksidasi lipid membran sel menjadikan membran sel pecah dan menjadikan isi sel tumpah keluar sehingga neuron mengalami nekrosis (37).

Propolis menunjukkan pemulihan aktivitas sintesis glutamat dan NO dengan penurunan stres oksidatif yang diperantarai eksitotoksisitas, sehingga propolis dapat menjadi pelindung terhadap eksitotoksititas dan gangguan neurodegeneratif sehingga proses terjadinya nekrosis juga terhambat (38). Penelitian lain juga menunjukan bahwa CAPE mempunyai efek antiinflamasi melalui inhibisi pada produksi ROS pada level transkripsi melalui supresi aktivasi NF-KB, dan dengan hambatan langsung pada aktifitas katalitik dari iNOS (36). Dengan demikian, penurunan area nekrosis pada penelitian model tikus TBI ini kemungkinan disebabkan oleh karena adanya kandungan flavonoid dan CAPE dari ekstrak propolis yang menghambat mekanisme tertentu yang dapat menyebabkan nekrosis.

\section{Hubungan Ekspresi TNF- $\alpha$ dan Apoptosis}

Penurunan jumlah sel apoptosis yang dikaitkan dengan penurunan TNF- $\alpha$ dapat dijelaskan sebagai berikut. Salah satu sinyal jalur TNF- merupakan jalur klasik yang dapat berfungsi untuk aktivasi jalur survival dimana dalam aktivitasnya menggunakan jalur NF-B, maupun jalur apoptosis dimana dalam aktivitasnya menggunakan kaskade caspase. Pada jalur TNF- didapatkan serangkaian proses yang kompleks untuk mencapai apoptosis. TNFberikatan dengan TNR1 dan kemudian merangsang TNFreceptor-associated death domain (TRADD), TNF-receptor factor-2 (TRAF-2) yang disebut sebagai "kompleks awal". Kompleks awal" yang sudah terbentuk, berikatan dengan Fas-associated death domain (FADD) yang selanjutnya melepaskan TNFR1 sehingga terbentuk kompleks baru

\section{DAFTAR PUSTAKA}

1. Nasution ES. Karakteristik Penderita Cedera Kepala Akibat Kecelakaan Lalu Lintas yang Rawat Inap di Rumah Sakit Padang Sidempuan. [Skripsi]. Universitas Sumatra Utara, Medan 2008 tanpa TNFR1. Kompleks ini mengaktifkan procaspase-8 menjadi caspase-8 teraktivasi. Dengan teraktivasinya caspase-8, maka kompleks yang baru terbentuk sebelumya, terurai menjadi molekul yang terpisah-pisah. Caspase-8 sebagai suatu molekul inisiator mengaktifkan caspase efektor, yaitu caspase-3. Hasil akhir dari tahap ini adalah caspase-3 yang mampu bertranslokasi ke inti untuk memulai apoptosis (40). Hal tersebut yang menjelaskan adanya hubungan yang searah antara TNF- $\alpha$ dengan apoptosis

Propolis mampu menurunkan reaksi inflamasi yang terjadi melalui hambatan terhadap aktivitas TNF- $\alpha$ dan NF-KB, sehingga diharapkan dapat mencegah komplikasi cedera sekunder yang mungkin terjadi (41). Dengan pemberian ekstrak propolis, respon inflamasi dan mediator-mediator inflamasi yang berlebihan seperti TNF- $\alpha$ dapat dihambat sehingga proses apoptosis akibat mediator inflamasi tersebut juga terhambat.

\section{Hubungan Ekspresi TNF- $\alpha$ dengan Nekrosis}

Berdasarkan hasil dapat dilihat bahwa semakin tinggi dosis ekstrak propolis memiliki kecenderungan untuk menurunkan area nekrosis pada jaringan otak tikus model cedera otak traumatic. Sinyal jalur TNF- $\alpha$ dapat menyebakan terjadinya nekrosis, salah satunya dengan mekanisme sinyal jalur TNF- melalui jalur NF-B. Jalur NF-B diaktifkan oleh reseptor TNF-, yaitu TNF tipe 1 atau 2 (TNFR1/2). Reseptor TNF- $\alpha$ tipe 1 disebutkan dapat menyebabkan respon seluler yang dapat menyebabkan apoptosis, nekrosis, survival dan inflamasi (40).

Propolis mampu menurunkan reaksi inflamasi melalui hambatan terhadap aktifitas TNF- $\alpha$ dan NF- $\kappa B$. Berdasarkan penelitian tersebut, dengan hambatan terhadap NF- $\mathrm{B}$, maka jalur terbentuknya nekrosis melalui TNF- $\alpha$ juga terhambat sehingga sesuai dengan hasil uji diatas bahwa didapatkan hubungan pada TNF- $\alpha$ dengan nekrosis (42). Selain itu, salah satu efek setelah terjadinya cedera kepala adalah peningkatan leukosit (PMN) dimana akan mempengaruhi sel neuron dan vaskularisasi darah. Terganggunya vaskularisasi darah tersebut selain menyebabkan kerusakan membran endotel juga menyebabkan peningkatan sitokin seperti IL1, IL6, IL 8 dan TNF- $\alpha$ karena terjadinya reperfusi jaringan. Peningkatan sitokin tersebut akan menyebabkan jaringan sklerotik dan akhirnya terjadi nekrosis. Selain itu, penelitian lain menyebutkan juga bahwa propolis mampu menurunkan reaksi inflamasi melalui hambatan terhadap aktifitas sitokin proinflamasi dan inflamasi seperti TNF- $\alpha$, IL 1, IL 8 $(43,44)$. Dengan demikian, pemberian ekstrak propolis menghambat mekanisme melalui jalur TNF- $\alpha$ sehingga proses terjadinya nekrosis juga terhambat.

Dari keseluruhan penelitian yang dilakukan ini dapat disimpulkan bahwa pemberian ekstrak propolis dapat menurunkan ekspresi TNF- $\alpha$, sel apoptosis dan area nekrosis pada jaringan otak tikus model traumatic brain injury (TBI), dan perlu dilakukan penelitian lebih lanjut untuk mengetahui titik kerja ekstrak propolis dalam menurunkan ekspresi TNF- $\alpha$, sel apoptosis dan area nekrosis.

2. Ansari S, Agius S, Debono P. Pediatric Head Injuries-A Review. Advances in Clinical Neuroscience \& Rehabilitation Journal. 2011; 10(6): 30-35.

3. Lisnawati, Kwandou L, Akbar M, Muis A, Kaelan C, and Patellongi I. Hubungan Skor Cognitive Test for Delirium 
(CTD) dengan Luaran Berdasarkan Glasgow Outcome Scale (Gos) pada Penderita Cedera Kepala Tertutup Ringan-Sedang. Jurnal Sains \& Teknologi. 2012; 2(2): 163-170.

4. Johnson VE, Stewart JE, Begbie FD, Trojanowski JQ, Smith $\mathrm{DH}$, and Stewart W. Inflammation and White Matter Degeneration Persist for Years after a Single Traumatic Brain Injury. Brain. 2013; 136(1): 28-42.

5. Katsanos GS, Anogeianaki A, Orso C, et al. Mast Cells and Chemokines. Journal of Biological Regulators and Homeostatic Agents. 2008; 22(3): 145-151.

6. Namas R, Ghuma A, Hermus L, et al. The Acute Inflammatory Response in Trauma/Hemorrhage and Traumatic Brain Injury: Current State and Emerging Prospects. Libyan Journal of Medicine. 2009; 4(3): 97103.

7. Albert-Weissenberger $C$ and Sirén AL. Experimental Traumatic Brain Injury. Experimental and Translational Stroke Medicine. 2010; 2:16

8. Berridge MJ. Cell Stress, Inflammatory Responses and Cell Death. Cell Signaling Biology. 2014; 11: 1-6.

9. Faul M, Xu L, Wald MM, and Coronado VG. Traumatic Brain Injury in the United States: Emergency Department Visits, Hospitalizations and Death 20022006. Atlanta: Centers for Disease Control and Prevention; 2010: pp. 1-74.

10. Enriquez $P$ and Bullock R. Molecular and Cellular Mechanisms in the Pathophysiology of Severe Head Injury. Current Pharmaceutical Design. 2004; 10(18): 2131-2143.

11. Kasan U. Cidera Kepala, Patofisiologi, Penanganan, dan Biomolekuler. Surabaya: Bagian Ilmu Bedah Saraf. RSU Dr Soetomo; 2006.

12. Bullock R, Chesnut R, Ghajar J, Gordon D, et al. Surgical Management of Acute Epidural Hematomas. Neurosurgery. 2006; 58(3): 7-15.

13. Werner C and Engelhard K. Pathophysiology of Traumatic Brain Injury. British Journal of Anaesthesia. 2007; 99(1): 4-9.

14. Spiotta AM, Stiefel MF, Gracias VH, et al. Brain Tissue Oxygen-directed Management and Outcome in Patients with Traumatic Brain Injury. Journal of Neurosurgery. 2010; 113(3): 571-580.

15. Platt S. The Role of Glutamate in Centrak Nervous System Health and Desease-A Review. The Veterinary Journal. 2007; 173(2): 278-286.

16. Li S, Wu C, Zhu L, et al. By Improving Regional Cortical Blood Flow, Attenuating Mitochondrial Dysfunction and Sequential Apoptosis Galangin Acts as a Potential Neuroprotective Agent after Acute Ischemic Stroke. Molecules. 2012; 17(11): 13403-13423.

17. Machfoed MH. Neurology Update: The Neuro-BioMolecular Mechanisms of Traumatic Brain Injury. Surabaya: Pustaka Cendekia Press; 2011; Hal. 1-10.

18. Mesbah L dan Samia A. Bioavailability and Pharmacokinetic of the Algerian Propolis Constituent Naringenin in Rats after Oral Administration. Planta Medicine. 2011; 77: 5-16.

19. Halim E, Hardinsyah, Sutandyo N, Sulaeman A,
Artika M, dan Harahap Y. Kajian Bioaktif dan Zat Gizi Propolis Indonesia dan Brasil. Jurnal Gizi dan Pangan. 2012; 7(1): 1-6.

20. Markiewicz-Zukowska R, Car H, Naliwajko SK, et al. Ethanolic Extract of Propolis, Chrysin, CAPE Inhibit Human Astroglia Cells. Advances in Medical Sciences. 2012; 57(2): 208-216.

21. Ozkara E, Durmaz R, Kanbak G, et al. The Effect of Propolis Following Experimental Spinal Cord Injury. World Spinal Column Journal. 2014; 5(1): 6-11.

22. Radiati EL, Al Awwaly KU, Kalsum U, dan Jaya F. Pengaruh Pemberian Ekstrak Propolis terhadap Sistem Kekebalan Seluler pada Tikus Putih (Rattus Novergicus) Strain wistar. Jurnal Teknologi Pertanian. 2008; 9(1): 1-9.

23. Syamsudin, Wiryowidagdo S, Simanjuntak $P$, and Heffen WL. Chemical Composition of Propolis from Different Region in Java and their Cytotoxic Activity. American Journal of Biochemistry and Biotechnology. 2009; 5(4):180-183.

24. Machado JL, Assuncao AKM, da Silva MCP, et al. Brazilian Green Propolis: Anti-Inflammatory Property by an Immunomodulatory Activity. Evidence Based Complementary and Alternative Medicine. 2012; 2012: 1-10.

25. Lukito H. Rancangan Penelitian, Suatu Pengantar. Malang: IKIP; 1998; Hal. 25-27.

26. Marmarou A, Signoretti S, Fatouros PP, Portella G, Aygok GA, and Bullock MR. Predominance of Cellular Edema in Traumatic Brain Swelling in Patients with Severe Head Injuries. Journal of Neurosurgery. 2006; 104(5): 720-730.

27. Hartati S.H, Sarsono, Aisyah S, dan Diding H.P. Ekstrak Etanol Propolis Menurunkan Kadar IL-17 Serum pada Mencit Balb/C Model Asma Kronik. Majalah Kedokteran Bandung. 2013; 45(4): 213-217.

28. Popova M, Bankova VS, Butovska D, et al. Poplar Type Propolis and Analysis of Its Biologically Active Components. Honeybee Science. 2003; 24(10): 61-66.

29. Ma ZG, Wang J, Jang H, Liu TW, and Xie JX. Myricetin Reduces 6-hydroxydopamine-induced Dopamin Neuron Degeneration in Rats. Neuroreport. 2007; 18(11): 1181-1185.

30. Ostrowska J dan Skrzydlewska E. The Biological Activity of Flavonoids. Postępy Fitoterapii. 2005; 3-4: 71-79.

31. Prasetyo D.H, Suparyanti EL, dan Guntur AH. Ekstrak Etanol Propolis Isolat Menurunkan Derajat Inflamasi dan Kadar Malondialdehid pada Serum Tikus Model Sepsis. Majalah Kedokteran Bandung. 2013: 45(3):161-166.

32. Sforcin JM and Bankovab V. Propolis: Is There a Potential for the Development of New Drugs? Journal of Ethnopharmacology. 2011; 133(2): 253-260.

33. Wu Z, Zhu A, Takayama F, et al. Brazilian Green Propolis Suppresses the Hypoxia-Induced Neuroinflammatory Response by Inhibiting NF-KB Activation in Microglia. Oxidative Medicine and Cellular Longevity. 2013; 2013: 10.

34. Newairy A and Abdou HM. Effect of Propolis Consumption on Hepatotoxicity and Brain Damage in 
Male Rats Exposed to Chlorpyrifos. African Journal of Biotechnology. 2013; 12(33): 5232-5243.

35. Geckil H, Ates B, Durmaz G, Erdogan S, and Yilmaz I. Antioxidant, Free Radical Scavenging and Metal Chelating Characteristics of Propolis. American Journal of Biochemistry and Biotechnology. 2005; 1(1): 27-31.

36. Kumazawa $\mathrm{Y}$, Kawaguchi $\mathrm{K}$, and Takimoto $\mathrm{H}$. Immunomodulating Effects of Flavonoids on Acute and Chronic Inflammatory Responses Caused by Tumor Necrosis Factor. Current Pharmaceutical Design. 2007; 12(32): 4271-4279.

37. Nortje J and Gupta AK. The Role of Tissue Oxygen Monitoring in Patients with Acute Brain Injury. British Journal of Anaesthesia. 2006; 97(1): 95-106.

38. Turkoglu AO, Sarmilmaz M, Kus I, et al. Cafeic Acid Phenethyl Ester (CAPE) Prevent FormaldehydeInduced Neuronal Damage in Hippocampus of Rat. Neuroanatomy. 2007; 6: 88-71.

39. Rajoo M, Parolia A, Pau A, and Amalraj FD. The Role of Propolis in Inflammation and Orofacial Pain: A Review. Annual Research \& Review in Biology. 2014; 4(4): 651-664.
40. Sawicka D, Car H, Borawska MH, and Niklinski J. The Anticancer Activity of Propolis. Folia Histochemica et Cytobiologica. 2012; 50(1): 25-37.

41. Tolba MF, Azab SS, Khalifa AE, Abdel-Rahman SZ, Abdel-Naim AB, Critical Review: Caffeic Acid Phenethyl Ester, a Promising Component of Propolis with a Plethora of Biological Activities: A Review on its Antiinflammatory, Neuroprotective, Hepatoprotective, and Cardioprotective Effects. International Union of Biochemistry and Molecular Biology Life. 2013; 65(8): 699-709.

42. Wang Y, Ge P, and Zhu Y. Review Article: TLR2 and TLR4 in Brain Injury Caused by Cerebral Ischemia and Reperfusion. Mediator of Inflammation. 2013; 2013: 8.

43. Zhu HT, Bian C, Yuan JC, et al. Curcumin Attenuates Acute Inflammatory Injury By Inhibiting The TLR4/Myd88/NF-Kb Signaling Pathway In Experimental Traumatic Brain Injury. Journal of Neuroinflammation. 2014; 11: 59.

44. Khalil ML. Biological Activity of Bee Propolis in Health and Disease. Asian Pacific Journal of Cancer Prevention. 2006; 7(1): 22-31. 